Abstracta Iranica Abstracta Iranica

Revue bibliographique pour le domaine irano-aryen

Volume 29 | 2008

Comptes rendus des publications de 2006

\title{
«Traduzione in volgare pisano di una lettera dell'Ilkhan di Persia al Re di Francia Filippo il Bello (1305) ». Bollettino Storico Pisano, 73, 2004, pp. 31-47.
}

\section{Giorgio Rota}

\section{(2) OpenEdition}

Journals

Édition électronique

URL : http://journals.openedition.org/abstractairanica/27652

DOI : 10.4000/abstractairanica.27652

ISSN : 1961-960X

Éditeur :

CNRS (UMR 7528 Mondes iraniens et indiens), Éditions de l'IFRI

Édition imprimée

Date de publication : 15 mai 2008

ISSN : 0240-8910

Référence électronique

Giorgio Rota, « " Traduzione in volgare pisano di una lettera dell'Ilkhan di Persia al Re di Francia Filippo il Bello (1305) ». Bollettino Storico Pisano, 73, 2004, pp. 37-47. », Abstracta Iranica [En ligne], Volume 29 | 2008, document 149, mis en ligne le 15 septembre 2008, consulté le 26 septembre 2020. URL : http:// journals.openedition.org/abstractairanica/27652; DOI : https://doi.org/10.4000/abstractairanica. 27652

Ce document a été généré automatiquement le 26 septembre 2020.

Tous droits réservés 
«Traduzione in volgare pisano di
una lettera dell'Ilkhan di Persia al Re di Francia Filippo il Bello (1305) ». Bollettino Storico Pisano, 73, 2004, pp. 31-47.

\author{
Giorgio Rota
}

The Author, who is also the editor of a 14th century Tuscan version (Florence, Biblioteca Nazionale, Ms. IV, II, 136) of Il Milione (cf. Marco Polo, Milione, ed. V.B.P., with a commented index by Giorgio R. Cardona, Milan, Adelphi, 1975; $3^{\text {rd }}$ edition, 2003) presents here an edition of the contemporary Italian translation of a letter sent by Öljeytü to Philip IV the Fair of France in 1305 (Paris, Archives Nationales, Document AE III 203, formerly Archives Royales J 937, n. 9), thus amending the transcription provided by Abel Rémusat in 1824. Since the Mongolian text is edited and well-known, the Author limits herself to the analysis of the Italian translation (although she reproduces the modern French translation of the Mongol original provided by Mostaert and Cleaves). The language of the translation (which is written on the reverse side of the document) appears to be a "Western Tuscan and more specifically Pisan" vernacular, perhaps as it could be spoken by an "emigrant" who had long left home, and with slight traces of French influences (p. 40). The writing style and the dating of the translation are also Pisan. Finally, the translator seems to have written the text himself. Given the connections between Pisa and the translation, and the few conclusions that one can draw about the anonymous translator, the Author suggests that a likely candidate might be the famous Ciolo Bofeti da Pisa, who was certainly still alive in 1301. 
INDEX

Thèmes : 4.1. Histoire médiévale

\section{AUTEURS}

GIORGIO ROTA

Institut für Iranistik - Wien 